\author{
A.D. Bolganbayev ${ }^{1}$, K. Myrzabekkyzy ${ }^{2}$, D.N. Kelesbayev ${ }^{3}$; \\ ${ }^{1,2,3}$ Khoja Akhmet Yassawi International Kazakh-Turkish University, Kazakhstan \\ lartur.bolganbayev@gmail.com, ${ }^{2}$ kundyz.myrzabekkyzy@ayu.edu.kz,3inmukhamed.kelesbayev@ayu.edu.kz \\ ${ }^{1}$ https://orcid.org/0000-0001-8476-6975, ${ }^{2}$ https://orcid.org/0000-0001-7207-4146, \\ ${ }^{3}$ http://orcid.org/0000-0002-4193-8121 \\ ${ }^{3}$ Scopus Author ID: 56623085400, ${ }^{3}$ ResearcherID: P-2783-2017
}

\title{
Analysis of the relationship between gross domestic product (GDP) and development of the transport industry in Kazakhstan
}

\begin{abstract}
Object: Logistics became a very crucial business in many countries. Meanwhile, the main transport routes connecting the continents of Asia and Europe pass through the territory of Kazakhstan. In this sense, Kazakhstan's geographical location is of commercial importance. Logistics amount to the $20 \%$ to $30 \%$ of the gross domestic product (GDP) in developed countries. This study aims to evaluate the effect of the changes in gross domestic product (GDP) on the developments in the transportation sector by analyzing the relation between the GDP and major indicators of the transportation sector.

Methods: The data obtained from this study is evaluated using time series analysis and regression analysis methods.

Findings: The transportation system is an important part of the infrastructure of Kazakhstan and has a great impact on the level of development of the country's economy. Therefore, analyzing these developments is very important both for understanding the development of the transport sector and for predicting the future of the sector. In this study, the relationship between the variables considered as the main indicator in the transportation sector and the gross national product was analyzed and the effect of the development in the gross national product on the developments in the transportation sector was determined.

Conclusions:H1a: The effect of GDP on FRTRANS is explained with the linear regression model; H1b: The effect of GDP on FRTTRANS is explained with the linear regression model; H1c: The effect of GDP on PSCTRANS is explained with the linear regression model; H1d: The effect of GDP on PSCTTRANS is explained with the linear regression model; H1e: The effect of GDP on FT_RAIL can't be explained with the linear regression model; H1f: The effect of GDP on PT_RAIL can't be explained with the linear regression model.
\end{abstract}

Keywords: Logistics, Logistics Centers, Transportation, GDP, Kazakhstan, Time Series Analysis, Regression Analysis.

\section{Introduction}

Kazakhstan is a country located in the intersection of major transportation routes and is one of the major players in the global retail markets-China, Russia, and Eastern and Western Europe. Hence, it holds promise as a possible route and location for modern logistics centers (LC) that will serve the new Silk Road. There are five international transit railway routes, six international transportation corridors, and many high-capacity pipelines within its borders. New international logistics centers that will be established by the Eurasian Economic Community (EurAsEC) until 2020 will also create additional prospects for the logistics services market in Kazakhstan (evrazes.com, 2018).

As such, the task of developing the transportation and logistics infrastructure continues to be relevant. For Kazakhstan, it is especially important to establish a logistic system based on regional centers. Such a system will improve the efficiency of the existing transportation infrastructure.

In Kazakhstan, the development of logistics effects, before anything else, the dynamics of the economic development, which requires the universalization of the transport system for it to serve the logistical needs adequately. Whereas the average GDP growth was $10,2 \%$ in the $2006-2007$ period, it became $2.3 \%$ and $6 \%$, respectively in the 2008-2009 and 2010-2014 periods (www.stat.gov.kz, 2018).

The economic growth of Kazakhstan raised to 4\% in 2014 with a balanced and widespread enlargement in all sectors of the economy. With the contribution of various positive factors, such as high global oil prices, a moderate increase in the oil production, continuing fiscal stimulus, and better global economic conditions,

\footnotetext{
* Corresponding author.

E-mail address: dinmukhamed.kelesbayev@ayu.edu.kz
} 
the national GDP is expected to grow $3.5 \%$ to $4 \%$ in 2018. In addition, the anticipated medium-term GDP growth in the $2018-2022$ period is $3.7 \%$.

The transportation infrastructure of Kazakhstan supports all kinds of transportation modes: such as railways, highways, pipelines (oil and gas lines), maritime lines (river and sea), and airways. In turn, Kazakhstan has many logistics capabilities that serve these modes: such as train stations, airports, service providers, repair and maintenance services, transport workers, and passenger services (Panasyuk et.al. 2013).

Transportation sector plays an important role in the Kazakhstan economy. The reason behind this fact is that Kazakhstan has vast lands, so its economy is commodity based. Railway transportation is the basis of the transportation infrastructure of the country with a freight volume of 237 billion tons/kilometer in 2016 (46\%). This ratio is $31 \%, 22 \%$, and $1 \%$ respectively for road transportation, pipeline transportation, and air and sea transportation.

Performance of the Kazakhstan logistics sector both in international and national trade is crucial for its national economic development. According to the 2018, World Bank Report, Kazakhstan ranked 71 among 160 countries in terms of logistics performance index (LPI). When compared with its status in 2016 (rank 77), this is an upward movement of six lines, and an upward movement of 17 lines when compared with its status in 2014 (rank 88). Kazakhstan improved and modernized its transportation infrastructure by investing to railroads, roads, and logistics infrastructure. Thus, Kazakhstan effectively integrates with global trade and made good headway in developing its transportation infrastructure (lpi.worldbank.org, 2018).

An important tool for the development of the logistics sector of the Republic of Kazakhstan is the investments in the logistics infrastructure (logistics centers, logistics parks, logistics areas, distribution centers, depots, etc.). According to the State Program on the development and integration of the transportation infrastructure until 2020 and the Transportation Strategy, 2015 (online.zakon.kz, 2018), the Republic of Kazakhstan is planning to build Transportation and Logistics Centers all around the country.

There are a lot of logistics centers and free trade areas in Kazakhstan. The best knowns are the HighTech Logistics Center in Almaty and DAMU-Almaty Industrial Logistics Center. The first one is used to transport the products imported from Russia and Europe to inland and the other Central Asian countries. Whereas the second provides integrated logistics services such as storage, shipping, custom procedures, and repackaging. Besides these, there are two TLC's in Astana and Shymkent. In addition, four more will be built in Aktobe and Pavlodar.

Whereas Aktobe TLC mostly handles transit cargos from Russia and Europe, Astana TLC handles cargos sent to Russian inland. DAMU depots in Almaty are only leased for storage. This terminal mainly handles cargos going to Central Asia, Mongolia, and China. Cargos to and from China (imports and exports) go to Dostık and Khorgos. Exports to the U.S.A. and Africa are sent through the port in Bandar Abbas and imports coming from there are handled in this port. Secondhand cars are mostly imported from the U.S.A.

The construction of Shymkent TLC (25 thousand meter square) cost approximately 15.8 billion KZT and was financed by the Development Bank of Kazakhstan. This center complies with the requirements for an A-class storehouse according to the international Knight Frank classification. The estimated area required to meet the storage and transportation needs of the southern region is 1 million meter squares. The volume of goods increased from 111 million tons in 2011 to 155 million tons in 2015 (www.sk.kz, 2018).

International Road Transportation Union has 317 member firms in Kazakhstan. International Transportation giants such as ECW Logistics (Netherlands), TKA Logistics (Germany), and Unico has branch offices in Kazakhstan. However, freight transports from Russia is mostly (approximately 90\%) done by small firms. The biggest of these are Selta LLC, Delovye Linii LLC, and Sovtransauto Group. The financial statements of these firms are not open to the public.

One can observe important developments in the transportation sector of Kazakhstan, especially after 2007. In parallel with the developments in its national economy, big steps are taken in the transportation sector, both in terms of its economic effect and its technical backbone. It is crucial to analyze these developments both to understand the development of the transportation sector and to estimate the future of the sector. This study aims to evaluate the effect of the changes in gross domestic product (GDP) on the developments in the transportation sector by analyzing the relation between the GDP and major indicators of the transportation sector.

The main hypothesis of this study is: H1: In Kazakhstan, GDP effects the developments in the transportation sector. We developed six more sub-hypotheses: H1a: The effect of GDP on the variable FRTRANS is explained with the linear regression model. H1b: The effect of GDP on the variable FRTTRANS is explained with the linear regression model. H1c: The effect of GDP on the variable PSCTRANS is explained with the 
linear regression model. H1d: The effect of GDP on the variable PSCTTRANS is explained with the linear regression model. H1e: The effect of GDP on the variable FT_RAIL is explained with the linear regression model. H1f: The effect of GDP on the variable PT_RAIL is explained with the linear regression model.

\section{Literature Review}

Nowakowski (Nowakowski, 2011) analyzed the projects proposed for the European Logistics Excellence Award in 2011 and formulated the trends of current logistics technologies applied by companies. He also presented the general assumptions of the winning projects.

Yerniyazova's (Yerniyazova, 2012) study has dealt with the fundamentals of state regulation of the transport industry and the experience of foreign countries in this field. The current situation and development trends of railway transport in the Republic of Kazakhstan are analyzed together with the current system of state regulation, aiming for further optimization.

Bodaubayeva's (Bodaubayeva, 2015) study addressed the theoretical and practical issues of the formation of industrial and logistics parks and focused on the idea of logistics integrating production, transportation, storage and distribution into a uniform commodity distribution chain. In addition, it offers a functioning model of industrial and logistics parks, which includes 4 blocks as logistics, industrial, innovative and administrative and service, and analyzes the development of logistics centers in Kazakhstan.

The study of Myrkhalykov et al. (Myrkhalykov et al., 2016) deals with the problem of evaluation and the current state of the transport system and its role in increasing the adaptability of the textile industry. The basis of the study of the development trends and prospects of the transport system and its role in increasing the adaptability of the textile industry is a modern economy that aims to increase the efficiency of individual sectors as a whole. The article draws attention to the transport system management experience and draws conclusions about the role of the textile industry in enhancing its adaptability.

Raimbekov et al. (Raimbekov et al., 2016) discusses Kazakhstan's freight-producing economy in their study. It covers transportation and logistics issues related to the necessary criteria of such services. Economic development of the production chain occurs. Suggestions are developed on the improvement of logistics services and efficiency of logistics units in the economic sectors that generate freight.

In the study of Muftigaliyeva et al. (Muftigaliyeva et al., 2016) strategic management questions, features of the formation and development of the railway industry of the Republic of Kazakhstan are shown. Special attention has also been paid to evaluating the strategic management of the real economy sector.

Suits et al. (Suits et al., 2017) examine the current situation of the transportation and logistics system and the problems from its location in order to increase the efficiency of the textile industry. The basis of the study was the current results of the authors in this field and the current trends in the modern course of the country's economy. Based on the programs and concepts adopted regarding the development of the industry, the course aims to increase the effectiveness of individual industries and their totals as a whole.

Daubayev et al. (Daubayev et al., 2017) states in their study that the transportation complex makes a significant contribution to the GDP of many developing countries. However, he also says that not all modern transport models fully meet the needs of modern society. Therefore, the purpose of his work is to improve the organizational and economic mechanisms of the development of the transport industry in the Republic of Kazakhstan and to address various technologies for it. The authors looked at the potential transport accessibility of the most demanding routes to create a universal transport infrastructure optimization model. Astana's transportation model was developed using mathematical modeling methods. The practical value of this research is that policy makers can use their results to optimize shipping flows and avoid additional shipping costs.

The article by Tasmaganbetov and Tasmaganbetova (Tasmaganbetov \& Tasmaganbetova, 2018) examines the role of the transport potential of the Republic of Kazakhstan in the development of logistics infrastructure in market conditions and aims to ensure the efficient movement of material flow, the determined role of information flow in the logistics system. The article also describes the role of logistics in the planning, management and control of the movements of materials, information and financial resources in different systems. In addition, the activities of Kazakhstan transport and logistics centers providing logistics services in the railway sector are analyzed.

Kunyazov (Kunyazov, 2019) discusses current priorities for the development of macro logistic systems of the Republic of Kazakhstan, which contributes to the development of innovation and import substitution in the industry and business sector. In the process of conducting the research, taking into account the international integration factors, existing production areas and macro logistic problems that hinder innovation with- 
in the framework of the functioning of vertical macro systems in the Republic of Kazakhstan were identified, and development and import substitution in economic sectors were formulated. Practical recommendations have been developed for each aspect that predetermines the increasing role of macro logistics systems in the innovative development of the economy and the implementation of import substitution business projects.

Allahverdieva et al. (Allahverdieva et al., 2019) analyze the peculiarities of the organization and development of the national transport system of the Republic of Kazakhstan, the current problems in their article. The article also includes the benefit of GDP in the transportation sector of the Republic of Kazakhstan in the transportation sector of the Republic of Kazakhstan, freight and turnover of the Republic of Kazakhstan, wage capacity and wage return, the depreciation rate of fixed assets in the transportation sector, lighting and labor productivity. The indicators, yield and capacity of the transportation sector in the Republic of Kazakhstan, the efficiency of the transportation sector, passenger traffic and passenger turnover in the Republic of Kazakhstan have been analyzed and evaluated.

In the article by Baibossynov et al. (Baibossynov et al., 2019), the main aspects of the further improvement of the socio-economic modernization of Kazakhstan are presented, the role of transport and logistics infrastructure is growing rapidly, taking an international dimension, and highlighting transport transit as one of the leading functions of the national transport system. Accordingly, it is necessary to determine the main trends in the development of the international logistics services market. As the Eurasian Economic Union, it is necessary to determine the impact aspects of the "Silk Road Economic Belt" initiatives in the development of the integration unions and Kazakhstan's transportation and logistics infrastructure.

The study by Zhen et al. (Zhen et al., 2019) solves a strategic level decision problem in determining the optimum location of logistics centers, taking into account the scale of facilities in an integrated closed loop supply chain network.

Chen et al. (Chen et al., 2019), in their study named 'Kerry Logistics - Paving the New Silk Road', touched upon China's logistics strategies, logistics expenditures, Silk Road, and its future. It also says that China's logistics spending is around $14.5 \%$ of its GDP, which is higher than that of other developing countries such as India and South Africa.

Safdar et al. (Safdar et al., 2020) have studied and developed a model to reduce environmental impact and increase social and economic impacts in reverse logistics network design. They considered a multipurpose reverse logistics network and triple result approach while developing the model.

Beknazarov et al. (Beknazarov et al., 2020) aimed to investigate the factors affecting the workforce in the supply chain in their study. In the study, they took the labor market of the Turkestan region of the Republic of Kazakhstan as the indicator region. According to the results, agricultural and industrial supply chains dominate the region and the former is significantly widespread. In addition, common factors affecting the labor surplus of a region (country) have been identified in the study based on the example of the region in question. The main factors are the high natural and mechanical population growth rate; high human resource growth rates, outpacing jobs growth; the dominant rural population; a deeper crisis in traditional industries and reduced business demand for the workforce.

\section{Methods}

We used data regarding six major indicators of the transportation sector and GDP between 2007Q1 and 2018Q2 (Table 1). We first analyzed the variables for stationarity. Non-stationary variables are transformed to stationary series with differential operations. Resulting series are used to create a linear regression model, which will be used to analyze the effect of GDP on six individual variables.

The time series is a cluster of values for a variable in time order; most commonly, it is taken at successive equally spaced points in time (Sevüktekin \& Çınar, 2014). The values do not need to be observed in equally spaced points in time. However, it is important for a healthy analysis.

In this study, we used the augmented Dickey-Fuller test to analyze the stationarity. Dickey-Fuller Test accepts the series of the null hypothesis $\left(H_{0}\right)$ as non-stationary (unit root exists). According to this hypothesis, big values of test statistics support the $H_{0}$ hypothesis.

A regression analysis aims to estimate the relationships between a dependent variable and one or more independent variables. When the degree of association is analyzed, the variables in question are classified into two groups, namely dependent and independent variables. Independent variables are the ones that can change without external intervention. Therefore, "results" are the ones that are classified as the dependent variables. It's important to note that there is a causal relationship between an independent and dependent variable. This is called the causality relation (Nakip, 2013). 
The significance of a regression model is determined by an ANOVA (F) test. A high statistical significance shows that the regression function describes the relationship between the independent and the dependent variable accurately, thus can be used for prediction. The statistical significance of variable coefficients (Beta coefficient) can be determined with a Student's t-test.

In the regression analysis, the explanatory force of the independent variable on the dependent variable is determined using the corrected coefficient of determination (corrected R-square). The square of the correlation coefficient (in case of a multi-variable regression, multi-correlation coefficient) is called the determination coefficient. In addition, the value of the determination coefficient, as calculated according to the number of dependent variables and data, is called the corrected coefficient of determination (corrected R-square). A high corrected R-square value proves the statically significance of the model. Therefore, it is used to compare models with different independent variables.

Variable (beta) coefficients of the model are interpreted as a correlation coefficient. A positive coefficient shows that the relation between the dependent and independent variables is in the same direction, whereas a negative coefficient shows that this relation is in the opposite direction. The standard regression coefficient shows the value of variables when converted to a standard normal variable. Witlessness of standard regression coefficients (independent of the measuring unit of variables) provides convenience in interpretation.

In a regression model using non-stationary variables, parameter estimations can be outside the reasonable limits and economical interpretation of results can be nonsensical even though we get significant tstatistics and high determination coefficients In case of spurious regression, the differences between variables can be used to estimate the regression model (Akdeniz, 2012).

\section{Results}

Definitions of study variables are given in Table 1. We used six major indicators of Kazakhstan transportation sector as variables. In addition, we analyzed the effect of GDP on these variables using regression analysis.

Table 1. Explanations regarding the Variables Used in the Study

\begin{tabular}{|l|l|}
\hline Variable Name & Variable Definition \\
\hline GDP & Gross Domestic Product \\
\hline FRTRANS & Transportation of freight luggage, thsd. tons \\
\hline FRTTRANS & Freight turnover, mln. ton $/ \mathrm{kms}$ \\
\hline PSCTRANS & Transportation of passengers, thsd. people \\
\hline PSCTTRANS & Passenger turnover, mln.passenger $/ \mathrm{kms}$ \\
\hline FT_RAIL & Freight turnover, $\mathrm{mln}$. ton $/ \mathrm{kms}$ \\
\hline PT_RAIL & Passenger turnover, mln.passenger $/ \mathrm{kms}$ \\
\hline
\end{tabular}

We provided explanatory statistics regarding these variables be given in Table 2 . We used data belonging to 2007Q1-2018Q2 period. Minimum, maximum, median and standard deviation values for all variables are presented.

Table 2. Explanatory Statistics on the Variables

\begin{tabular}{|l|l|l|l|l|}
\hline & Minimum & Maximum & Median & Std. Deviation \\
\hline GDP & 2536234,900 & 17959216,600 & 8010275,198 & 3734611,540 \\
\hline FRTRANS & 416255,770 & 1133505,910 & 763444,873 & 205580,115 \\
\hline FRTTRANS & 77115,960 & 153493,900 & 113467,333 & 22111,827 \\
\hline PSCTRANS & 2328337,700 & 6083403,530 & 4345824,803 & 1176203,743 \\
\hline PSCTTRANS & 25345,600 & 72620,500 & 50320,404 & 14765,499 \\
\hline FT_RAIIL & 43956,600 & 76130,600 & 57236,066 & 7595,411 \\
\hline PT_RAIIL & 2945,500 & 6765,700 & 4408,424 & 949,684 \\
\hline
\end{tabular}

Stationarity of the variables is analyzed with the augmented Duckey-Fuller test and resulting data is given in Table 3. Unit root test showed that the variable FT RAIIL is stationary. We also determined that the first difference of the variables FRTRANS, PT_RAIIL and PSCTTRANS, and the second difference of the variables GDP, FRTTRANS and PSCTRANS are stationary. 
Table 3. Analysis Results on the Stationarity of the Variables

\begin{tabular}{|c|c|c|c|c|c|c|}
\hline & & \multicolumn{3}{|c|}{ Critical Values } & \multicolumn{2}{|c|}{ Results } \\
\hline & & $1 \%$ & $5 \%$ & $10 \%$ & T-statistic & P-value \\
\hline \multirow[t]{3}{*}{ GDP } & Level & $-4,1985$ & $-3,52362$ & $-3,1929$ & $-2,208653$ & 0,4724 \\
\hline & I. Difference & $-4,1985$ & $-3,52362$ & $-3,1929$ & $-2,794332$ & 0,2074 \\
\hline & II. Difference & $-4,1985$ & $-3,52362$ & $-3,1929$ & $-56,62221$ & $\mathbf{0 , 0 0 0 0}$ \\
\hline \multirow[t]{2}{*}{ FRTRANS } & Level & $-4,1985$ & $-3,52362$ & $-3,1929$ & $-0,186267$ & 0,9913 \\
\hline & I. Difference & $-4,19234$ & $-3,52079$ & $-3,19128$ & $-14,85733$ & $\mathbf{0 , 0 0 0 0}$ \\
\hline \multirow[t]{3}{*}{ FRTTRANS } & Level & $-4,1985$ & $-3,52362$ & $-3,1929$ & $-1,58557$ & 0,7814 \\
\hline & I. Difference & $-4,1985$ & $-3,52362$ & $-3,1929$ & $-1,68803$ & 0,7385 \\
\hline & II. Difference & $-4,1985$ & $-3,52362$ & $-3,1929$ & $-16,73685$ & $\mathbf{0 , 0 0 0 0}$ \\
\hline FT_RAIL & Level & $-4,17564$ & $-3,51308$ & $-3,18685$ & $-3,89485$ & 0,0204 \\
\hline \multirow[t]{2}{*}{ PT_RAIL } & Level & $-4,17564$ & $-3,51308$ & $-3,18685$ & $-2,252577$ & 0,4501 \\
\hline & I. Difference & $-4,19234$ & $-3,52079$ & $-3,19128$ & $-6,399821$ & $\mathbf{0 , 0 0 0 0}$ \\
\hline \multirow[t]{3}{*}{ PSCTRANS } & Level & $-4,1985$ & $-3,52362$ & $-3,1929$ & 0,784545 & 0,9996 \\
\hline & I. Difference & $-4,1985$ & $-3,52362$ & $-3,1929$ & $-0,718535$ & 0,9648 \\
\hline & II. Difference & $-4,1985$ & $-3,52362$ & $-3,1929$ & $-13,97578$ & $\mathbf{0 , 0 0 0 0}$ \\
\hline \multirow[t]{2}{*}{ PSCTTRANS } & Level & $-4,19234$ & $-3,52079$ & $-3,19128$ & 0,736902 & 0,9995 \\
\hline & I. Difference & $-4,19234$ & $-3,52079$ & $-3,19128$ & $-5,853327$ & $\mathbf{0 , 0 0 0 1}$ \\
\hline
\end{tabular}

As a result, we used the stationary difference levels of variables for regression analysis.

Table 4. Linear Regression Model Findings between FRTRANS and GDP

\begin{tabular}{|l|l|l|l|l|}
\hline & Regression Coefficients & Standard Regression Coefficients & T & P \\
\hline CONSTANT & 2301,624 & & 0,135 & 0,894 \\
\hline GDP & 0,027 & 0,692 & 6,206 & 0,000 \\
\hline R & R square & Corrected R square & F & P \\
\hline, $692^{\mathrm{a}}$ & 0,478 & 0,466 & 38,521 &, $000^{\mathrm{a}}$ \\
\hline
\end{tabular}

When the explanatory variable (independent variable) is GDP, and the explained variable (dependent variable) is FRTRANS, the resulting linear regression model is given in Table 4. ANOVA test proved this model statistically significant. Besides the coefficient of determination (corrected) was 0.466. Therefore, in this model, GDP could explain the $46.6 \%$ of the variations in FRTRANS. Besides, there is a linear relation in the positive direction between these two variables as the correlation coefficient $(0.692)$ proved. Student's ttest showed that the coefficient for the GDP variable is statistically significant. According to these results, we wrote the formula for the regression line as FRTRANS $=\mathbf{2 3 0 1 , 6 2 4}+\mathbf{0 , 0 2 7 x G D P}$. According to the standard regression coefficient, a one-point increase in the GDP causes a 0.692 unit increase in FRTRANS.

Table 5. Linear Regression Model Findings between FRTTRANS and GDP

\begin{tabular}{|l|l|l|l|l|}
\hline & Regression Coefficients & Standard Regression Coefficients & T & P \\
\hline CONSTANT & $-1140,070$ & & $-0,600$ & 0,551 \\
\hline GDP & 0,004 & 0,780 & 8,068 & 0,000 \\
\hline R & R square & Corrected R square & F & P \\
\hline, $780^{\mathrm{a}}$ & 0,608 & 0,598 & 65,088 &, $000^{\mathrm{a}}$ \\
\hline
\end{tabular}

When the explanatory variable (independent variable) is GDP, and the explained variable (dependent variable) is FRTTRANS, the resulting linear regression model is given in Table 5. ANOVA test proved this model statistically significant. Besides the coefficient of determination (corrected) was 0.598 . Therefore, in this model, GDP could explain the $59.8 \%$ of the variations in FRTTRANS. Besides, there is a linear relation in the positive direction between these two variables as the correlation coefficient $(0.780)$ proved. Student's t-test showed that the coefficient for the GDP variable is statistically significant. According to these results, we wrote the formula for the regression line as FRTTRANS $=\mathbf{- 1 1 4 0 , 0 7 0}+\mathbf{0 , 0 0 4 x G D P}$. 
According to the standard regression coefficient, a one-point increase in the GDP causes a 0,780 -unit increase in FRTTRANS.

Table 6. Linear Regression Model Findings between PSCTRANS and GDP

\begin{tabular}{|l|l|l|l|l|}
\hline & Regression Coefficients & Standard Regression Coefficients & T & P \\
\hline CONSTANT & $-47507,704$ & & $-0,678$ & 0,502 \\
\hline GDP & 0,099 & 0,645 & 5,470 & 0,000 \\
\hline R & R square & Corrected R square & F & P \\
\hline, $645^{\text {a }}$ & 0,416 & 0,402 & 29,922 &, $000^{\text {a }}$ \\
\hline
\end{tabular}

When the explanatory variable (independent variable) is GDP, and the explained variable (dependent variable) is PSCTRANS, the resulting linear regression model is given in Table 6. ANOVA test proved this model statistically significant. Besides the coefficient of determination (corrected) was 0.402 . Therefore, in this model, GDP could explain the $40.2 \%$ of the variations in PSCTRANS. Besides, there is a linear relation in the positive direction between these two variables as the correlation coefficient $(0.645)$ proved. Student's t-test showed that the coefficient for the GDP variable is statistically significant. According to these results, we wrote the formula for the regression line as PSCTRANS $=\mathbf{- 4 7 5 0 7 , 7 0 4 + 0 , 0 9 9 x G D P}$. According to the standard regression coefficient, a one-point increase in the GDP causes a 0,645-unit increase in PSCTRANS.

Table 7. Linear Regression Model Findings between PSCTTRANS and GDP

\begin{tabular}{|l|l|l|l|l|}
\hline & Regression Coefficients & Standard Regression Coefficients & $\mathbf{T}$ & $\mathbf{P}$ \\
\hline CONSTANT & 333,614 & & 0,403 & 0,689 \\
\hline GDP & 0,001 & 0,388 & 2,731 & 0,009 \\
\hline R & R square & Corrected R square & F & P \\
\hline, $388^{\text {a }}$ & 0,151 & 0,131 & 7,459 &, $009^{\text {a }}$ \\
\hline
\end{tabular}

When the explanatory variable (independent variable) is GDP, and the explained variable (dependent variable) is PSCTTRANS, the resulting linear regression model is given in Table 7. ANOVA test proved this model statistically significant. Besides the coefficient of determination (corrected) was 0.131 . Therefore, in this model, GDP could explain the $13.1 \%$ of the variations in PSCTTRANS. Besides, there is a linear relation in positive direction between these two variables as the correlation coefficient $(0.388)$ proved. Student's t-test showed that the coefficient for the GDP variable is statistically significant. According to these results,

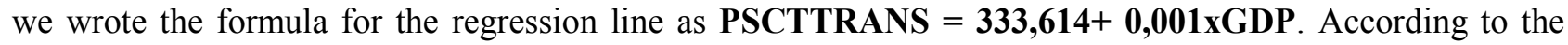
standard regression coefficient, a one-point increase in the GDP causes a 0,388-unit increase in PSCTTRANS.

Table 8. Linear Regression Model Findings between PT_RAİL and GDP

\begin{tabular}{|l|l|l|l|l|}
\hline & Regression Coefficients & Standard Regression Coefficients & T & P \\
\hline CONSTANT & $-23,110$ & & $-0,222$ & 0,825 \\
\hline GDP & 0,000 & 0,009 & 0,056 & 0,956 \\
\hline R & R square & Corrected R square & F & P \\
\hline, $009^{\text {a }}$ & 0,000 & $-0,024$ & 0,003 &, $956^{\text {a }}$ \\
\hline
\end{tabular}

When the explanatory variable (independent variable) is GDP, and the explained variable (dependent variable) is PT_RAIL, the resulting linear regression model is given in Table 8. ANOVA test failed to show any statistically significant relation in this model. As a result, GDP has no effect on PT_RAIL.

Table 9. Linear Regression Model Findings between FT_RAİL and GDP

\begin{tabular}{|l|l|l|l|l|}
\hline & Regression Coefficients & Standard Regression Coefficients & T & P \\
\hline CONSTANT & 57683,632 & & 50,772 & 0,000 \\
\hline GDP & 0,000 & 0,042 & 0,271 & 0,788 \\
\hline R & R square & Corrected R square & F & P \\
\hline, $042^{\mathrm{a}}$ & 0,002 & $-0,022$ & 0,073 &, $788^{\mathrm{a}}$ \\
\hline
\end{tabular}


When the explanatory variable (independent variable) is GDP, and the explained variable (dependent variable) is FT_RAIL, the resulting linear regression model is given in Table 9. ANOVA test failed to show any statistically significant relation in this model. As a result, GDP has no effect on FT_RAIL.

\section{Conclusions}

The transportation sector is very important for Kazakhstan and is a rapidly developing sector in her economy. While some modes of transportation are characterized as an oligopoly (airline, railway, and pipeline transportation), other modes are characterized by free competition (railroad and naval transportation).

Transportation has shown rapid development in the last decade in the Republic of Kazakhstan, both because of her national market and her relations with other states. Sector plays an important role in the region both is economy and sociology. However, its development is not homogenous throughout the region.

When compared with developed countries, transportation sector of Kazakhstan is not competitive. Its share in GDP and total investments tends to drop; therefore, the sector does not have sustainable development.

In conclusion:

H1a: The effect of GDP on FRTRANS is explained with the linear regression model;

H1b: The effect of GDP on FRTTRANS is explained with the linear regression model;

H1c: The effect of GDP on PSCTRANS is explained with the linear regression model;

H1d: The effect of GDP on PSCTTRANS is explained with the linear regression model;

H1e: The effect of GDP on FT_RAIL can't be explained with the linear regression model;

H1f: The effect of GDP on PT_RAIL can't be explained with the linear regression model.

\section{References}

Akdeniz, F. (2012). Olasılık ve İstatistik. Adana: Nobel Kitabevi.

Allahverdieva, L.M., Kurmanalina, A.A. \& Tasmaganbetova, S.Zh. (2019). Features, problems and prospects of development of the national transport system of the Republic of Kazakhstan. Bulletin of the Karaganda university, Economy series, 2 (94), 212-223.

Baibossynov, S.B., Akenov, S.Sh. \& Kasymova, N.Sh. (2019). Priority directions of development of transport and logistics infrastructure of Kazakhstan at the present stage. Bulletin of the Karaganda university Economy series, 3 (95), 201-208.

Beknazarov, B., Niyazbekova, R., Ilasheva, S., Statsenko, O., Turalina, S., Yessenbekova, S. \& Assilov, S. (2020). Labor force and supply chains: Mutual influence of socio-economic factors (Republic of Kazakhstan). International Journal of Supply Chain Management, 9 (3), 791-798.

Bodaubayeva, G. (2015). Formation of industrial and logistic parks in Kazakhstan. Conference paper of $4^{\text {th }}$ IEEE International Conference on Advanced Logistics and Transport, France, 41-46.

Chen, I.S.N., Luk, S.T.K. \& Tao, J. (2019). Kerry Logistics-Paving the New Silk Road. Asian Case Research Journal, 23 (1), 153-191.

Daubayev, K., Kerimbek, A., Vermaganova, S., Aitkaliyeva, A., Zhalbinova, S., Jrauova, K., Kaltaev, A. \& Sugurova, A. (2017). The transport model as a necessary condition for the construction of an efficient transport system. Espacios, 38 (54), 222-230.

Kunyazov, E.K. (2019). Ways to intensify innovation and import substitution in macro logistic systems of the Republic of Kazakhstan in the context of international integration. Bulletin of the Karaganda University, Economy series, 4 (96), 220-230.

Logistics Performance Index: Connecting to Compete. (2018). Retrieved from http://lpi.worldbank.org/international/global/2018, Access 01.12.2019.

Muftigaliyeva, A., Kuangaliyeva, T., Ibyzhanova, A., Mirzageldy, K., Kaigorodzev, A., Baigabulova, K. \& Sargaeva, N. (2016). Innovative approaches in the development of Kazakhstan railway industry. Journal of Advanced Research in Law and Economics, 7 (4), 851-861.

Myrkhalykov, Zh.U., Issambayeva, A.Zh., Yessirkepova, A.M. \& Issayeva, G.K. (2016). Rating rank Kazakhstan in the transit transport communication with the standpoint of the development of the textile industry. Proceedings of Higher Educational Institutions, Technology Series of the Textile Industry, 3, 25-32.

Nakip, M. (2013). Pazarlamada Araştırma Teknikleri. Ankara: Seçkin Yayıncılık.

Nowakowski, T. (2011). Analysis of modern trends of logistics technology development. Archives of Civil and Mechanical Engineering, 11 (3), 699-706.

Panasyuk, M.V., Gafurov, I.R. \& Novenkova, A.Z. (2013). Influence of international transport and logistics systems on economic development of the region. World Applied Sciences Journal, 27, 135-139.

Raimbekov, Z., Syzdykbayeva, B., Yergaliyev, R. \& Sarsenova, A. (2016). Development of logistics and supply chains in freight-generating sectors of economy. Economic Annals-XXI, 156 (1-2), 97-100. 
Safdar, N., Khalid, R., Ahmed, W. \& Imran, M. (2020). Reverse logistics network design of e-waste management under the triple bottom line approach. Journal of Cleaner Production, 272, 122-132.

Sevüktekin, M. \& Çınar, M. (2014). Ekonometrik Zaman Serileri Analizi. Bursa: Dora Yayıncılık.

Socio-Economic Indicators of the Republic of Kazakhstan. (2019). Retrieved from http://www.stat.gov.kz/, Access 27.11.2019.

State Program for the Development and İntegration of Transport Infrastructure of the Republic of Kazakhstan till 2020: Kazakhstan Presidential Decree from 12.10.2014. (2014). Retrieved from https://online.zakon.kz/Document/?doc id=31497811, Access 23.11.2019.

Strategy of Creation and Development of İnternational Logistics Centers of the Eurasian Economic Community. (2008). Retrieved from http://evrazes.com/docs/view/434, Access 24.11.2019.

Suits, V.P., Raimbekov, Z.H.S., Issambayeva, A.Zh., Agabekova, G.N. \& Yessirkepova, A.M. (2017). Transport and logistics system as a development factor of the textile sphere of the republic of Kazakhstan. Proceedings of Higher Educational Institutions, Technology Series of the Textile Industry, 372 (6), 54-61.

Tasmaganbetov, A.B. \& Tasmaganbetova, S.Zh. (2018). Contemporary issues of transport logistics development in Republic of Kazakhstan. Bulletin of the Karaganda University, Economy series, 2 (90), 108-114.

Transport Strategy of the Republic of Kazakhstan till 2015: Presidential Decree from 11.04.2006. (2006). Retrieved from https://online.zakon.kz/Document/?doc_id=30051598, Access 27.11.2019.

The Research and Knowledge Management Department Strategy and Portfolio Investment Block of JSC "SamrukKazyna". (2017). Retrieved from https://www.sk.kz/research/?temp=full\&id=272\&year=2017, Access 23.11.2019.

Yerniyazova, Z. (2012). Grounds for state regulation of transport system in the Republic of Kazakhstan. Actual Problems of Economics, 137 (11), 310-320.

Zhen, L., Sun, Q., Wang, K. \& Zhang, X. (2019). Facility location and scale optimisation in closed-loop supply chain. International Journal of Production Research, 57 (24), 7567-7585.

\section{А.Д. Болғанбаев, Қ. Мырзабекқызы, Д.Н. Келесбаев \\ Қазақстандағы көлік өнеркәсібінің дамуы мен жалпы ішкі өнім арасындағы байланысты талдау}

\section{Аңдатna}

Maқ̧cambl: Көптеген шет мемлекеттерде логистика көп жылдардан бері іскери құрал болып келеді. Осы орайда Азия мен Еуропа континенттерін байланыстыратын негізгі көлік бағыттары Қазақстан арқылы өтеді. Бұл тұрғыдан алғанда Қазақстанның географиялық орналасуының коммерциялық маңызы өте зор. Осындай логистикалық жүйелер жетекші өнеркәсіптік дамыған елдердің жалпы ішкі өнімдерінің (ЖІӨ) 20-30 \%-ын құрайды. Бұл зерттеу жұмысының мақсаты, көлік секторындағы негізгі көрсеткіштер ретінде бағаланған айнымалылар мен жалпы ішкі өнім арасындағы байланысты талдау арқылы жалпы ішкі өнімнің дамуы көлік секторындағы оқиғаларға қаншалықты әсер ететінін анықтау болып табылады.

Әдісі: Көлік өнеркәсібі мен жалпы ішкі өнім арасындағы байланысқа қатысты жиналған деректер уақыт сериясы және регрессия әдістері арқылы талданған.

Kорытынды: Көлік жүйесі Қазақстандық инфрақұрылымның маңызды бөлігі болып табылады және ел экономикасының даму деңгейіне үлкен әсер етеді. Осы жағдайларды талдау көлік өнеркәсібінің дамуын түсіну және бұл саланың болашағын болжау тұрғысынан өте маңызды. Сол себепті, зерттеуде көлік өнеркәсібінің дамуы мен жалпы ішкі өнім арасындағы байланыс талданып, жалпы ішкі өнімнің өсуі көлік өнеркәсібінің дамуына қаншалықты әсер ететіндігі анықталды.

Тұжырымдама: Алынған нәтижелерге сәйкес мына гипотезалар қабылданды: Н1а: ЖІӨ айнымалысының FRTRANS айнымалысына әсері сызықтық регрессия моделімен түсіндіріледі; Н1b: ЖІӨ айнымалысының FRTTRANS айнымалысына әсері сызықтық регрессия моделімен түсіндіріледі; Н1с: ЖІӨ айнымалысының PSCTRANS айнымалысына әсері сызықтық регрессия моделімен түсіндіріледі және Н1d: ЖІӨ айнымалысының PSCTTRANS айнымалысына әсері сызықтық регрессиялық модельмен түсіндіріледі. Ал мына гипотезалар қабылданбады: H1e: ЖIӨ айнымалысының FT_RAIL айнымалысына әсерін сызықтық регрессия моделімен түсіндіруге болмайды және H1f: ЖІӨ айнымалысының PT_RAIL айнымалысына әсерін сызықтық регрессия моделімен түсіндіруге болмайды.

Kiлm сөздер: логистика, логистикалық орталықтар, көлік өнеркәсібі, ЖІӨ, Қазақстан, уақыт сериясы, регрессиялық талдау.

\section{А.Д. Болганбаев, К. Мырзабеккызы, Д.Н. Келесбаев}

\section{Анализ взаимосвязи между развитием транспортной промышленности и валового внутреннего продукта в Казахстане}

\section{Аннотация}

Цель: Во многих зарубежных странах логистика была инструментом бизнеса на протяжении многих лет. В связи с этим основные транспортные маршруты, соединяющие континенты Азии и Европы, проходят через Казахстан. С этой точки зрения географическое положение Казахстана имеет большое коммерческое значение. 
Такие логистические системы составляют 20-30\% валового внутреннего продукта (ВВП) ведущих промышленно развитых стран мира. Целью данного исследования является анализ взаимосвязи между переменными и валовым внутренним продуктом, оцениваемых как ключевые показатели в транспортном секторе для определения степени, в которой рост ВВП повлияет на события в транспортном секторе.

Meтоды: Собранные данные о взаимосвязи между транспортной отраслью и ВВП были проанализированы с использованием анализа временных рядов и методов регрессии.

Pезультаты: Транспортная система является важной частью инфраструктуры Казахстана и оказывает существенное влияние на уровень развития экономики страны. Анализ этих процессов очень важен с точки зрения значимости развития транспортной отрасли и прогнозирования будущего этой отрасли. Поэтому в данном исследовании исследована взаимосвязь между развитием транспортной отрасли и ВВП, а также выявлено влияние роста ВВП на развитие транспортной отрасли.

Bblвoдbl: Согласно полученным результатам были приняты следующие гипотезы: Н1а: влияние переменной ВBП на переменную FRTRANS объясняется моделью линейной регрессии; Н1b: влияние переменной ВBП на переменную FRTTRANS объясняется моделью линейной регрессии; Н1с: влияние переменной BBП на переменную PSCTRANS объясняется моделью линейной регрессии и Н1d: влияние переменной BВП на переменную PSCTTRANS объясняется моделью линейной регрессии. Следующие гипотезы были отклонены: H1е: влияние переменной ВВП на переменную FT_RAIL нельзя объяснить моделью линейной регрессии и H1f: влияние переменной ВВП на переменную PT_ $\bar{R} A I L$ нельзя объяснить моделью линейной регрессии.

Ключевые слова: логистика, логистические центры, транспортная отрасль, ВВП, Казахстан, анализ временных рядов, регрессионный анализ.

\section{References}

Akdeniz F. Olasılık ve İstatistik [text]: book / Akdeniz, F. — Adana: Nobel Kitabevi, 2012.

Allahverdieva L.M. Features, problems and prospects of development of the national transport system of the Republic of Kazakhstan [text] / L.M. Allahverdieva, A.A. Kurmanalina, S.Zh. Tasmaganbetova // Bulletin of the Karaganda university, Economy series. — 2019. — № 2(94). — P. 212-223.

Baibossynov, S.B. Priority directions of development of transport and logistics infrastructure of Kazakhstan at the present stage [text] / S.B. Baibossynov, S.Sh. Akenov, N.Sh. Kasymova // Bulletin of the Karaganda university, Economy series. — 2019. — № 3(95). — P. 201-208.

Beknazarov B. Labor force and supply chains: Mutual influence of socio-economic factors (Republic of Kazakhstan) [text] / B. Beknazarov, R. Niyazbekova, S. Ilasheva, O. Statsenko, S. Turalina, S. Yessenbekova, S.Assilov // International Journal of Supply Chain Management. — 2020. — № 9(3). — P. 791-798.

Bodaubayeva G. Formation of industrial and logistic parks in Kazakhstan [text] / G. Bodaubayeva // 4th IEEE International Conference on Advanced Logistics and Transport. - 2015. - P. 41-46.

Chen I.S.N. Kerry Logistics-Paving the New Silk Road [text] / I.S.N. Chen, S.T.K. Luk, J. Tao // Asian Case Research Journal. — 2019. — № 23(1). — P. 153-191.

Daubayev K. The transport model as a necessary condition for the construction of an efficient transport system [text] / K. Daubayev, A. Kerimbek, S. Vermaganova, A. Aitkaliyeva, S. Zhalbinova, K. Jrauova, A. Kaltaev, A. Sugurova // Espacios. — 2017. — № 38(54). — P. 222-230.

Kunyazov E.K. Ways to intensify innovation and import substitution in macro logistic systems of the Republic of Kazakhstan in the context of international integration [text] / E.K. Kunyazov // Bulletin of the Karaganda University, Economy series. — 2019. — № 4(96). - P. 220-230.

Logistics Performance Index: Connecting to Compete [online] - (http://lpi.worldbank.org/international/global/2018).

Muftigaliyeva, A. Innovative approaches in the development of Kazakhstan railway industry [text] / A. Muftigaliyeva, T. Kuangaliyeva, A. Ibyzhanova, K. Mirzageldy, A. Kaigorodzev, K. Baigabulova, N. Sargaeva // Journal of Advanced Research in Law and Economics. — 2016. — № 7(4). — P. 851-861.

Myrkhalykov Zh.U. Rating rank Kazakhstan in the transit transport communication with the standpoint of the development of the textile industry [text] / Zh.U. Myrkhalykov, A.Zh. Issambayeva, A.M. Yessirkepova, G.K. Issayeva // Proceedings of Higher Educational Institutions, Technology Series of the Textile Industry. — 2016. — №3. - P. 25-32.

Nakip M. Pazarlamada Araştırma Teknikleri [text]: book / M. Nakip. — Ankara: Seçkin Yayıncılık, 2013.

Nowakowski T. Analysis of modern trends of logistics technology development [text] / T. Nowakowski // Archives of Civil and Mechanical Engineering. — 2011. — № 11(3). — P. 699-706.

Panasyuk M.V. Influence of international transport and logistics systems on economic development of the region [text] / M.V. Panasyuk, I.R. Gafurov, A.Z. Novenkova // World Applied Sciences Journal. — 2013. — № 27. — P. 135139.

Raimbekov Z. Development of logistics and supply chains in freight-generating sectors of economy [text] / Z. Raimbekov, B. Syzdykbayeva, R. Yergaliyev, A. Sarsenova // Economic Annals-XXI. — 2016. — № 156(1-2). - P. 97-100. 
Safdar N. Reverse logistics network design of e-waste management under the triple bottom line approach [text] / N. Safdar, R. Khalid, W. Ahmed, M. Imran // Journal of Cleaner Production. — 2020. — № 272. — P. $122-132$.

Sevüktekin M. Ekonometrik Zaman Serileri Analizi [text]: book / M. Sevüktekin, M. Çınar. — Bursa: Dora Yayıncılık, 2014.

Socio-Economic İndicators of the Republic of Kazakhstan [online] — (http://www.stat.gov.kz/).

State Program for the Development and İntegration of Transport İnfrastructure of the Republic of Kazakhstan till 2020 [online] — (https://online.zakon.kz/Document/?doc_id=31497811).

Strategy of Creation and Development of İnternational Logistics Centers of the Eurasian Economic Community [online] - (http://evrazes.com/docs/view/434).

Suits V.P. Transport and logistics system as a development factor of the textile sphere of the republic of Kazakhstan [text] / V.P. Suits, Z.H.S. Raimbekov, A.Zh. Issambayeva, G.N. Agabekova, A.M. Yessirkepova // Proceedings of Higher Educational Institutions, Technology Series of the Textile Industry. — 2017. — № 372(6). — P. 54-61.

Tasmaganbetov A.B. Contemporary issues of transport logistics development in Republic of Kazakhstan [text] / A.B. Tasmaganbetov, S.Zh. Tasmaganbetova // Bulletin of the Karaganda University, Economy series. — 2018. — № 2(90). - P. 108-114.

Transport Strategy of the Republic of Kazakhstan till 2015 [online] — (https://online.zakon.kz/Document /?doc_id=30051598).

The Research and Knowledge Management Department Strategy and Portfolio Investment Block of JSC "SamrukKazyna" [online] — (https://www.sk.kz/research/?temp=full\&id=272\&year=2017).

Yerniyazova Z. Grounds for state regulation of transport system in the Republic of Kazakhstan [text] / Z. Yerniyazova, // Actual Problems of Economics. — 2012. — № 137(11). — P. 310-320.

Zhen L. Facility location and scale optimisation in closed-loop supply chain [text] / L. Zhen, Q. Sun, K. Wang, X. Zhang // International Journal of Production Research. — 2019. — № 57(24). — P. 7567-7585. 